\title{
Olivier Pedeflous, La lecture de Claudien dans les collèges au XVI ${ }^{\mathrm{e}}$ siècle
}

\section{Filippo Fassina}

\section{OpenEdition \\ Journals}

\section{Edizione digitale}

URL: http://journals.openedition.org/studifrancesi/9452

DOI: 10.4000/studifrancesi.9452

ISSN: 2421-5856

\section{Editore}

Rosenberg \& Sellier

\section{Edizione cartacea}

Data di pubblicazione: 1 décembre 2007

Paginazione: 636

ISSN: 0039-2944

\section{Notizia bibliografica digitale}

Filippo Fassina, «Olivier Pedeflous, La lecture de Claudien dans les collèges au xvie siècle», Studi Francesi [Online], 153 (LI | III) | 2007, online dal 30 novembre 2015, consultato il 13 janvier 2021. URL: http:// journals.openedition.org/studifrancesi/9452 ; DOI: https://doi.org/10.4000/studifrancesi.9452

Questo documento è stato generato automaticamente il 13 janvier 2021.

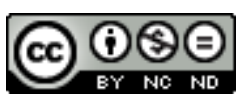

Studi Francesi è distribuita con Licenza Creative Commons Attribuzione - Non commerciale - Non opere derivate 4.0 Internazionale. 


\title{
Olivier Pedeflous, La lecture de Claudien dans les collèges au XVI siècle
}

\author{
Filippo Fassina
}

\section{NOTIZIA}

OLIVIER PEDEFLOUS, La lecture de Claudien dans les collèges au XVI siècle, «Bibliothèque d'Humanisme et Renaissance», LXIX, 1 (2007), pp. 55-82.

1 Il presente studio offre un quadro dettagliato della diffusione e della circolazione nel XVI secolo delle opere di Claudiano, la cui fortuna fu di breve durata e legata quasi esclusivamente ad ambienti eruditi. L'A. esamina dunque l'uso che si faceva di tali opere - il De raptu Proserpinae su tutte - all'interno dei collèges francesi, identificando gli ambiti in cui serviva da modello: lo stile e la metrica, gli insegnamenti morali (utili in special modo ai pedagoghi) e il repertorio mitologico offerto. La seconda parte del lavoro è, invece, dedicata all'esame delle edizioni di Claudiano a partire da un Rapt de Proserpine (1517) annotato da Jean de Gourmont. Infine, vengono prese in considerazione le vite del poeta che precedono le varie edizioni, dalle quali emergono ulteriori interpretazioni sull'utilità e l'importanza del corpus claudianeo. 